Historic, Archive Document

Do not assume content reflects current scientific knowledge, policies, or practices. 



\title{
The Barnes Bros. Nursery Co. Yalesville, Conn,
}

TERMS ON WHICH WE SELL NURSERY STOCK

\author{
Important-Please Read Carefully
}

Bank drift or money order, payable to the Barnes Brothers Nursery Company, must accompany all Srders amounting to $\$ 25$ or less, a cash discount of 5 per cent being allowed on the total amoun:

WE WI SHIP LARGER ORDERS C. O. D., p oviding 25 per cent of the total amount of your order is sent in cash. If the order is shipped by EXPRESS, you pay the balance to your EXPRESS A ENT upon delivery of goods.

If the ord goes by FREIGHT, you pay the balance at YOUR BANK, where you will also If the ord lading, which you present to your freight agent, who will deliver shipment to you. find the bill c-WE ALLOW A CASH DISCOUNT OF 5 PER CENT ON ALL ORDERS, large or small, for which the total amount with order is remitted.

\section{TRANSPORTATION RULES}

Our goc ds are sold F. O. B. Cars at the point of shipment and travel at the purchaser's risk and gocause of the present unsettled conditions, we wish to emphasize still further that we do not guarantee safe delivery. The ownership of all goods sold by us passes to the purchaser after delivery $\mathrm{L}^{\mathrm{y}} \mathrm{us}$ to the carrier, and the issuing of a receipt by the carrier ends our responsibility. Any claims for lamage should be made promptly to the agent of the transportation company at the point of delivery.

\section{THE BARNES BROS. NURSERY CO. YALESVILLE, CONN.}

CLAIMS, if any, must be made upon receipt of goods, when they will be carefully and cheerfully examined, and, if just, satisfactory adjustments will be made with purchaser. Claims made after five days from receipt of goods will not be entertained.

NON-WARRANTY. (1) If any nursery stock shall prove untrue to the label under which it is sold, provided notice and proper proof thereof are furnished by the purchaser, to the seller, the seller shall at the option of the purchaser, either refill that portion of the order which was mislabeled, by another delivery of stock, or refund the purchase price; but in any case, we are not to be held responsible for a sum greater than the original selling price of such stock. (2) All sales or agreements of sale are made subject to shortage of nursery stock, fire, frost, floods, drought, or other causes beyond the control of seller.

INSPECTION. Our Nurseries have been thoroughly inspected and found free from San Jose Scale and other injurious insects or diseases. Certificate accompanies.

WE CANNOT REPLACE STOCK GRATIS. These prices do not include any guarantee, of growth. We will guarantee our stock to be in first-class condition when delivered to our railroad station, but, unless customer insures, we will not be responsible for stock which may not grow, as we have no control of it after it leaves our hands. We will guarantee the growth of stock for 30 par cent over and above prices in this list-payable before shipment and subject to conditions named on our printed order blank. If you lose this order blank, we will be glad to send you another but failure to use our printed form for placing of orders, and also to insure the stock, will be interpreted as meaning that the customer assumes his own risk of the stock growing.

PARCEL POST. We cannot ship by parcel post any trees larger than 3 to $4 \mathrm{ft}$. in height. We strongly recommend that strawberries be ordered shipped by parcel post, large orders by express. Be sure to include postage in your remittance which can be estimated as follows in 1 st. and 2 nd. zones.

$\begin{array}{ll}\text { NO CHARGE LESS THAN } & .05 \\ \text { Asparagus } 2 \text { yr. } & .20 \text { per } 100 \\ \text { " } 3 \text { yr. } & .30 ", ",\end{array}$

Roses, perennials, berry bushes "except strawberries. 1st. plant .05; each additional plant .01 .

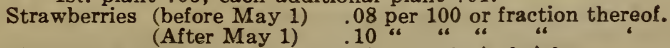

Shrubs and small trees not exceeding 3-4 ft. in height.

.05 for first specimen

01 for each additional specimen

APPLICATION OF RATES. Customers may select six of any particular variety at dozen rates, fifty at hundred rates or five hundred at thousand rates, such as 6 Baldwin or 50 Baldwin.

SIZE OF ORDERS. Owing to high costs incident to the handling of orders, we cannot accept orders amounting to less than $\$ 2.50$. 
FRUIT DEPARTMENT 1920

These prices supersede ail previous lists. APPLES, 2 yr.

$1 / 2-\frac{2}{36}$ in. cal., 4 to $5 \mathrm{ft}$.

Each
$\$ .75$

Doz.

$\$ 7.50$

8.50 100

$\$ 50.00$

65.00

.95

9.50

$\frac{1}{16}$ in. cal. and up, 5 to $7 \mathrm{ft}$.

\section{Bellflower \\ Chenango \\ Early Harvest \\ Golden Sweet \\ Oldenburg}

Fall Pippin

* Gravenstein

Hubbardston

Hurlbut

*King

*McIntosh

*Baldwin

Ben Davis

Boiken

Canada Red

Delicious

English Russett

Fallawater

Fameuse

Gano

Gilliflower

Grimes

Golden Russett

*Jonathan

Lady

Lady Sweet

*Maiden Blush

Newton Pippin

Hyslop
SUMMER APPLES

Porter

*Red Astrachan

Sweet Bough

Williams

*Yellow Transparent

AUTUMN APPLES

*Opalescent

Rambo

Walter Pease

*Wealthy

*Wolf River

WINTER APPLES

*Northern Spy

Peck's Pleasant

*Rhode Island Greening

*Rome Beauty

*Roxbury Russet

Smith Cider

Stayman Winesap

Sutton Beauty

Talman Sweet

Wagenor

*Winter Banana

Winesap

York Imperial

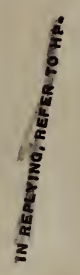

CRAB-APPLES Standard

Prices same as Apples

Transcendent star.

(Transplanted)

We can supply those varieties on dwarf Doucin (semi-dwarf) stock which are marno. fith 2

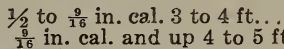

Each Doz.

$\$ .85 \$ 8.50$

Dwarf Baldwin only on Paradise stock (Full dwarf)

PEACHES

2 to $3 \mathrm{ft}$

$3 / 8$ to $\frac{7}{16}$ in. cal. 3 to 4

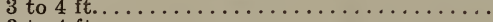

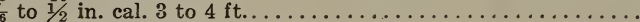

$1 / 2$ to $\frac{9}{16}$ in. cal. 4 to $5 \mathrm{ft} . \ldots \ldots \ldots \ldots \ldots \ldots \ldots \ldots \ldots \ldots \ldots \ldots \ldots \ldots \ldots$

If to $5 / 8$ in. cal. 4 to $6 \mathrm{ft}$.

.

GENERAL LIST OF VARIETIES

Each Doz.

$\begin{array}{rr}\$ .60 & \$ 7.00 \\ .70 & 8.00\end{array}$

$\begin{array}{ll}.70 & 8.00 \\ .80 & 8.50\end{array}$

$.85 \quad 9.00$

$.90 \quad 10.00$

$95 \quad 11.00$

9.50

8 in.

Belle of Georgia

Carman

Champion

Connett's

Early Crawford

Early Elberta

Elberta

Eva

Fox

Francis

Greensbore

J. H. Hale

Hiely

Iron Mountain

Late Crawford

Lizzie
Mayflower
Miss Lola
Mountain Rose
Nectar
Old Mixon
Ray
Rochester
Salway
Smock
Stevens
Stump
Tena
Toughina

THE STUBENRAUCH PEACHES

THE GREATEST ADVANCE IN THE PEACH INDUSTRY SINCE THE ORIGINATION OF THE ELBERTA

This group of varieties is the result of the lifelong work of Mr. J. W. Stubenra sch, of Mexia, Texas, the originator of the well-known Carman. A natural-born scientist, he has cross-pollinated, pianted and cross-pollinated again, always with the end in view that the results should finally bring forth varieties more hardy, more prolific, and of far better quality than any then in existence. and his efforts have not been in vain, as we can judge from the varieties which will soon be described.

One may presume that Texas would be too far south to test the hardiness of buds, but in reality the Texas climate gives one of the most severe tests to the Peach, both on account of freezes and summer drought. 
We have received by mail samples of all varieties described and must admit that they stood the journey remarkably well and have even remained in fine condition in our office for a week without' refrigeration of any kind.

These are new in all sections except Texas, but in comparison with the Elberta, in quality, productiveness and hardiness, they not only deserve a standing with that variety; lengthening the season by fully six weeks, but promise to revolutionize our present orchard standard varieties.

This is the second year we have offered these.new varieties to the public, and we have only a limited quantity. We can sell any only a few to each customer, and while they last will dispose of them at price of other varieties.

\section{DESCRIPTION OF VARIETIES}

EVA. Equal to Elberta in size, more round, nearly covered with red, similar quality. Fruit ripens several days in advance of Elberta and tree is a sure bearer.

ANITA. Ripens 10 days after Elberta. Seems to be a reproduction of same. Quality is very similar, but tree is even more prolific.

TENA. Ripens with Elberta, of same size, perhaps a little more color, and better quality. Very prolific bearer.

TOUGHINA. Ripens a week after Elbertà. Mr. Stubenrauch says of it: "In size, this Peach is very large, some specimens weighing 12 ounces. The color is a bright yellow, nearly covered with beautiful red. . This is practically a nectarine, has no fuzz at all, and skin as tough as a turnip, the flesh quite juicy, and of highest quality. Quality is far better than Elberta or even Hale, which I have growing close by. Owing to its blooming later, it escapes injury by cold when the Elbertas are killed. Speaking of the Hale, it is certainly ahead of Elberta, and, side by side, Toughina is yet decidedly ahead of Hale."

LIZZIE. Ripens two weeks after Elberta. Is of light lemon-yellow, with nice red eheeks; fine shipper. Good quality and size with very little fuzz.

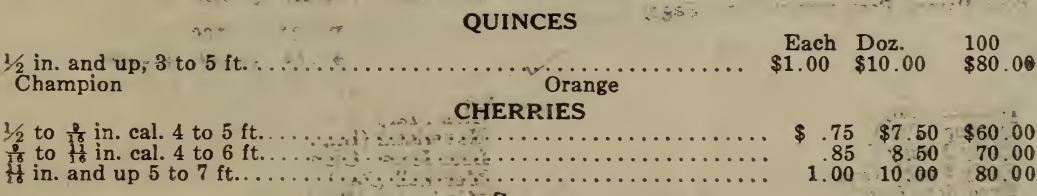

\section{Montmorency \\ Early Richmond \\ Napoleon Bigarreau \\ Windsor \\ Schmidt's Bigarreau}

$1 / 2$ to $\frac{0}{16}$ in. cal. 4 to $5 \mathrm{ft}$.

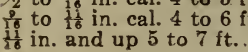

Abundance
Fu-bank
Red June
Beauty of Naples
German Prune
Grand Duke
Fellemberg

$1 / 2$ to $\frac{9}{15}$ in. cal. 4 to $5 \mathrm{ft}$.

$\frac{2}{16}$ to $\frac{12}{26}$ in. cal. 4 to $6 \mathrm{ft}$

$\frac{12}{16}$ in. cal. and up, 5 to $7 \mathrm{ft}$

*Anjou (Beurre d'Anjou)

*Bartlett

*Clapp's Favorite

* Duchess

Flemish

Garber

Sour

English Morello

Sweet

Yellow Spanis h

Black Tartarian

\section{PLUMS}

We have a very few Beurre Ḃose for spring '20 at the following prices:



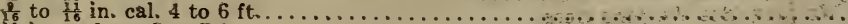

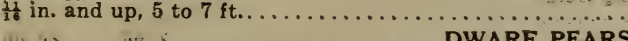

We can supply dwarf pears in those varieties marked with

GRAPES 2 yer. No. 1

Concord (B), Clinton (B)

(B) black, (W) white, (R) Red Each

Agawan, (R), Catawba, $(R)$

Pocklington (W)

Moores Diamond (W)

Delaware (R)

Moore's Early (B),

Wyoming Red (R)

PEARS

Lombard

Ponds Seedling

Reine Claude

Shropshire Damson

Campbells Early (B), Eaton (W)

Green Mountain (W)
* Ijawrence

Seckel

Sheldon

Wilder

Worden Seckel

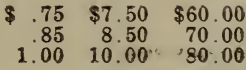

$\begin{array}{rrr}.85 & 8.50 & 70.00 \\ 1.00 & 10.00 & 80.00\end{array}$

$\begin{array}{lrr}.75 & \$ 7.50 & \$ 50.00 \\ .85 & 8.50 & 65.00 \\ .95 & 9.50 & 75.00\end{array}$

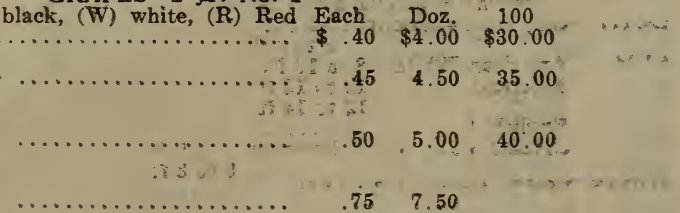

$\$ 8.50$ per doz. 


\section{NUT TREES}

Butternut, 3 to $4 \mathrm{ft}$.

Walnut, English $11 / 2$ to $2 \mathrm{ft}$.

Black Walnut, 3 to $4 \mathrm{ft}$.

Japanese Walnut, 4 to $5 \mathrm{ft}$

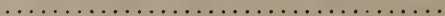

ft.

Japanese Chestnut, 3 to $4 \mathrm{ft}$
Spanish Chestnut, 3 to $4 \mathrm{ftr}$

CURRANTS

Red Cross, 2 yr. No. 1

Perfection, 2 yr. No.

Fays prolific, 1 yr.

GOOSEBERRIES, 2 yr. No. $i$

Houghton (Red), Downing (Whitish Green)

Pearl (White) ..........................

RASPBERRIES

Each Doz.

$\$ 1.25 \quad \$ 12.50$

$\begin{array}{rr}.85 & 8.50\end{array}$

1.00

1.00

10.00

10.00

10.00

1.00
1.00

10.00

$\begin{array}{ccc}\text { Each } & \text { Doz. } & 100 \\ \$ .45 & \$ 4.50 & \$ 25.00\end{array}$

1,000

40.00

$20.00 \$ 150.00$

$3.50 \quad 20.00$

50.00

$\$ .75 \quad 7.50$

Doz. $100 \quad 1,000$

Cumberiand, Plum Farmer

Kansas, Gregg, Columbian (purple)

St. Regis (Everbearing), Cuthbert,

King, Herbert

Red

$\$ 1.50 \quad \$ 6.00 \quad \$ 40.00$

BLÄCKBERRIES

$\$ 1.50 \quad \$ 6.00 \quad \$ 40.00$

Eldorado, Synder, Mercereúa STRAWBERRIES (For Spring delivery on $\$ 1.50 \quad \$ 7.50$ (See Parcel Post instructions Page)

\author{
Abington (Per.) \\ Bubach (Imp.) \\ Dunlop (Per.) \\ Early Jersey Giant (Per.) \\ Early Ozark (Per.) \\ Excelsior (Imp.) \\ Oom Paul (Per.) \\ Parsons Beauty (Per.) \\ Prolific (Imp.) \\ Sample (Imp.) \\ Sharpless (Per.)
}

Superb (Per.)

Progressive (Per.)

ASPARAGUS

2 yr...

3 yr.

Paimetto

Giant Argenteil

Per 25 per100 per1000

Varieties

$\$ .75 \quad \$ 1.50 \quad \$ 12.50$
EVERBEARING

Per 25 per 100

$\$ 1.50 \quad \$ 4.00$
Haverland (Imp.)

Late Jersey Giant (Per.)

Marshall (Per.)

Missionary (Per.)

(Per.)

uccess (Per.)

Wm. Belt. (Per.) 
LARCH, European, 3 to $4 \mathrm{ft}$

1.00

2.50

3.00

$10 \mathrm{to} 12 \mathrm{ft}$.

1.25

4.00

4.00

4.00

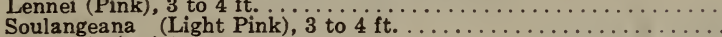

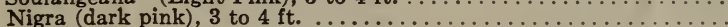

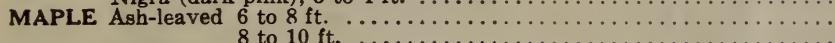

Schwedler's 6 to $8 \mathrm{ft}$.

1.00

1.25

3.00

3.50

1.00

10.00

16 to $18 \mathrm{ft}$.

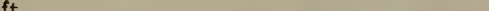

18 to $20 \mathrm{ft}$.

Sugar 8 to $10 \mathrm{ft}$.

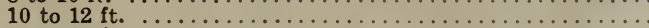

12 to $14 \mathrm{ft}$.

14 to $16 \mathrm{ft}$.

16 to $18 \mathrm{ft}$.

Weir's Cut-leaved,

Norway 8 to $10 \mathrm{ft}$.

$$
10 \text { to } 12 \mathrm{ft}
$$

12 to $14 \mathrm{ft}$

14 to $16 \mathrm{ft}$

Japanese varieties.

Japanese

MOUNTAIN ASH, European, 5 to $7 \mathrm{ft}$

OAK, American Red, 5 to $6 \mathrm{ft}$.

$$
\text { Pin. } 6 \text { to } 8 \mathrm{ft} \text {. }
$$

Scarlet 5 to $6 \mathrm{ft}$.

10 to $12 \mathrm{ft}$.

POPLAR Carolina 6 to $8 \mathrm{ft}$.

Lombardy 6 to $8 \mathrm{ft}$.

Silver, $\quad 5$ to $10 \mathrm{ft}$.

THORN, Paul's, 3 to $4 \mathrm{ft}$.

$$
\begin{aligned}
& 8 \text { to } 10 \mathrm{ft} \text {. } \\
& 5 \text { to } 6 \mathrm{ft} \text {. } \\
& 6 \text { to } 8 \mathrm{ft} \text {. }
\end{aligned}
$$

TULIP TREE, 5 to $6 \mathrm{ft}$. Spring only

WILLOW, Half-weeping (Salix elegantissima) 5 to $7 \mathrm{ft}$.

Weeping (Babylonica), 5 to $7 \mathrm{ft}$.

8 to $10 \mathrm{ft}$.

$$
8 \text { to } 10 \mathrm{ft} \text {. }
$$

Laurel-leaved (pentandra), 5 to $7 \mathrm{ft}$.

Golden Bark (vitellina eurea), 5
Red Bark (Britzensis), 5 to $7 \mathrm{ft}$.

\section{WEEPING DECIDUOUUS TREES}

APPLE, Weeping, $4 \mathrm{yr}$. heads on $6 \mathrm{ft}$. stems

ASH, Mountain, 4 yr. heads on $6 \mathrm{ft}$. stems

BEACH Weeping, Purple Beach, 4 to $5 \mathrm{ft}$.

BIRCH, Cut-leaved, Weeping, 6 to $8 \mathrm{ft}$.

WILLOW See above

ARBORVITAE, American 1 to $11 / 2 \mathrm{ft}$.

\section{EVERGREENS}

Each

$\$ 3.00$

3.00

$\$ .75$
10.00

25. 0.0

30.00

12.50

10.00

12.50

30.00

35.00

10.00

100.00

150.00

20.00

30.00

40.00

60.00

100.00

15.00

20.00

30.00

45.00

60.00

100.00

25.00

15.00

20.00

25.00

30.00

45.00

20.00

7.50

10.00

7.50

10.00

7.50

10.00

12.50

12.50

10.00

12.50

10.00

12.50

10.00

10.00

10.00

Doz.

4.00

2. 00

$\$ 40.00$ 20.00

1.00

1.50

2.00

2.50

1. 50

2. 00

2.00

2.50

1.50

2.00

2.50

1.00

1.50

2.00

3.00

1. 50

2.00

1.50

1. 50

2.00

1.50

2.00

3.50

6.00

2.00

1 to $11 / 2 \mathrm{ft}$.

$11 / 2$ to $2 \mathrm{ft}$

2 to $3 \mathrm{ft}$.

$\$ 7.50$

10.00

15.00

20.00

25.00

15.00

20.00

20.00

25.00

15.00

20.00

25.00

10.00

15.00

20.00

30.00

15.00

20.00

15,00

15.00

20.00

15.00

20.00

35.00

60.00

20.00

$11 / 2$ to $2 \mathrm{ft}$.
15. 00

1. 50

20,00 
Excelsa Stricta (dwarf) 1 to $11 / 2 \mathrm{ft}$.

20.00

Globesa varigata (dwarf) 10 to 12 in.

JUNIPER, Japonica. 1 to $11 / 2 \mathrm{ft}$ 3 to $4 \mathrm{ft}$.

200

30.00

Neborionsis, 1 to $11 / 2 \mathrm{ft}$.

$2.00 \quad 2.000$

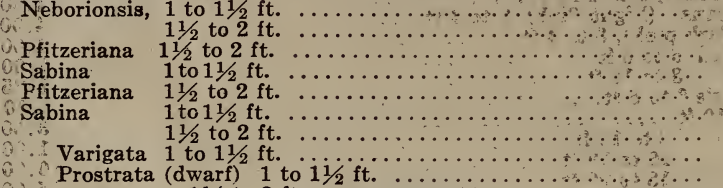

Prostrata (dwarf) 1 to $11 / 2$ ft.

Tamariscifolia $11 / 2$ to $2 \mathrm{ft}$.

1.50 . 15.00

$2.00 \% \quad 20.00$

2.50. 25.00

$2.00 \quad 20.00$

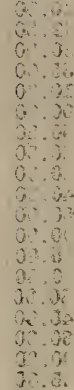

$\begin{array}{ll}2.50 & 25.00 \\ 2.00 & 20.00\end{array}$

$2.50 \quad 25.00$

2. 50

2.50

25.00

25.00

3. 50

35.00

25.00

30.00

Virginiana (Red Cedar)

3.00

Cannarti,

2 to $3 \mathrm{ft}$.

1.25

12.50

20.00

30.00

Glauca (bluish)

2 to $3 \mathrm{ft}$.

3. 00 .

3.50

35.00

20.00

Globosa (dwarf)

1 to $11 / 2 \mathrm{ft}$

2.00

$11 / 2$ to $2 \mathrm{ft} . \ldots \ldots \ldots \ldots \ldots \ldots \ldots \ldots \ldots \ldots \ldots \ldots$

Schotti

8 to 12 in.

25.00

1 to $11 / 2 \mathrm{ft}$.

2.50

1.50

$11 / 2$ to $2 \mathrm{ft} . \quad \ldots \ldots \ldots \cdots \cdots \cdots \cdots \cdots$

Smithi

1 to $11 / 2 \mathrm{ft}$

2.00

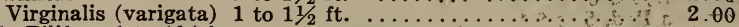

RETINOSPORA, Filifera 1 to $11 / 2 \mathrm{ft}$.

1.50 2 to $3 \mathrm{ft}$.

3.00

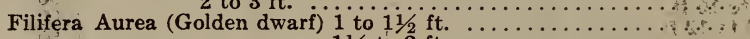

3. 00

$11 / 2$ to $2 \mathrm{ft}$. $\ldots \ldots \ldots \ldots \ldots \ldots .3 .50$

Plumosa, 1 to $11 / 2 \mathrm{ft}$.

1. 50

2. 50

$11 / 2$ to $2 \mathrm{ft}$.

2.00

1. 00

Fisifera 1 to $1 \frac{1}{2} \mathrm{ft}$.

2.00

$11 / 2$ to $2 \mathrm{ft}$
1 to $11 / 2 \mathrm{ft}$

2. 00

2. 50

$11 / 2$ to $2 \mathrm{ft}$

2. 50

2. 00

squarosa Veitchii (bluish) , 1 to $11 / 2$

PINES

Austrian $\quad 11 / 2$ to $2 \mathrm{ft}$.

PINES

(Jack (Banksiana 2 to $3 \mathrm{ft}$. . . . . .

3 to $4 \mathrm{ft}$. $\ldots \ldots \ldots \ldots \ldots \ldots$

Bull (Ponderosa) 2 to $3 \mathrm{ft}$.

2.00

2.50

2. 00

2.50

3 to $4 \mathrm{ft}$

2. 00

2. 50

Mugho,(Dwarf) 1 to $11 / 2 \mathrm{ft}$.

2. 50

3. 00

2.00

Școtch

$11 / 2$ to $2 \mathrm{ft}$.

2.50

White

2 to $3 \mathrm{ft}$.

2.00

2. 50 .

15.00

20.00

25. 00

20.00

20.00

15.00

30.00

30.00

35.00

15.00

25.00

20.00

15.00

20.00

20.00

$-25.00$

$25: 00$

20.00

20.00

25.00

20.00

25.00

20.00

25.00

25.00

30:00,

20.00.

25.00

20.00

25.00

Red,

2 to $3 \mathrm{ft}$.

25.00

Spruce

Colorado

SPRUCES

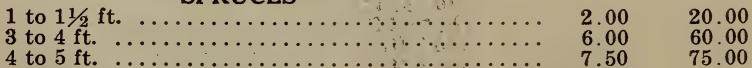

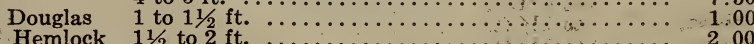

Hemlock

10.00

20.00

25.00

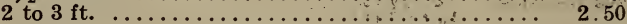

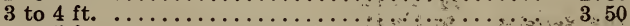

35.00

50.00

3.50
1.00

Koster Blue 1 to $11 / 2 \mathrm{ft}$.

35.00

10.00

13.5

12.50

1.25

2 to $3 \mathrm{ft}$.

1.50

15. 00

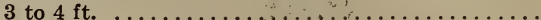

4 to $5 \mathrm{ft}$. . . .

2.00

20.00

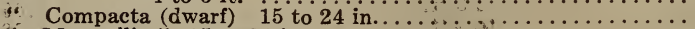

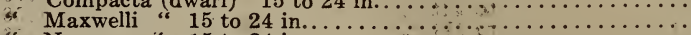

i. Nana 15 to 24 in.

5.00

5.00

White

1 to $11 / 2 \mathrm{ft}$.

5. 00

10.00

YEWS

$\begin{array}{lll}\text { TAXUS } & \text { Capitata } & 11 / 2 \text { to } 2 \mathrm{ft} . \\ & \text { Cuspidata } & 11 / 2 \text { to } 2 \mathrm{ft} \text {. }\end{array}$

" brevifolia (dwarf), 1 to $11 / 2 \mathrm{ft}$

2. 50

25.00

3.50

35.00

3. 50

35.00

20.00

$11 / 2$ to $2 \mathrm{ft}$.

3.00

30.00 


\section{HEDGE PLANTS, Deciduous}

BARBERRY, Thunberg's PRIVET California

Amoor River Ibota Privet
1 to $11 / 2 \mathrm{ft}$.
$11 / 2$ to $2 \mathrm{ft}$.

20.00

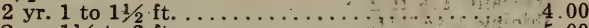

2 yr. $11 / 2$ to 2 ft. ............. 5.00

2 yr. 2 to $3 \mathrm{ft} . \ldots \ldots \ldots \ldots \ldots \ldots \ldots \ldots$

$2 \mathrm{yr} .3$ to $4 \mathrm{ft}$. ................. 10.00

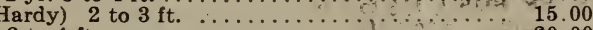

3 to $4 \mathrm{ft}$. . . . . . . .

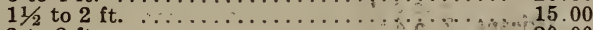

2 to $3 \mathrm{ft}$.

HEDGE PLANTS, Evergreen

AMERICAN ARBORVITAE 1 to $11 / 2 \mathrm{ft}$.

\section{NORWAY SPRUCE}

MOUNTAIN LAUREL

\section{BUXUS Box Tree. None for sale.}

\section{UPRIGHT SHRUBS}

Upright, clean bright stock, strictly first-class. The size inentioned after-each variety is that considered as proper for first-clas plants, suitable for transplanting. The size varies according to the habit of growth of the varieties mentioned, as, of course, some plants when fully grown are smaller than others, but equally as good.

ALTHEA Double or Single, Pink, Purple Red, White, 2 to $3 \mathrm{ft}^{-} \quad$ Each Doz.

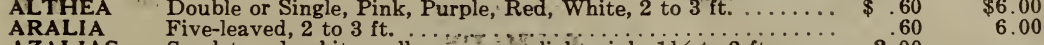
AZALIAS, Scarlet, red, white, yellow, orange, light pink, $11 / 2$ to $2 \mathrm{ft} . \ldots \ldots$ 2.00

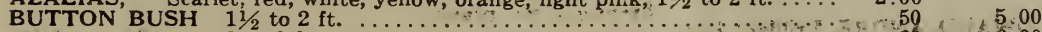

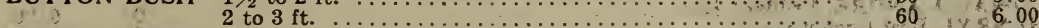
CORNUS MAS. Cornelian Cherry, 2 to $3 \mathrm{ft}$ Stolonifera (Red-branched), 2 to $3 \mathrm{ft}$.

Siberica, 2 to $3 \mathrm{ft}$. 3 to $4 \mathrm{ft}$.

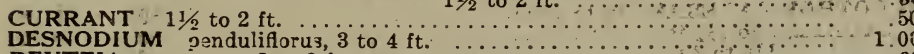
ii 2 tor

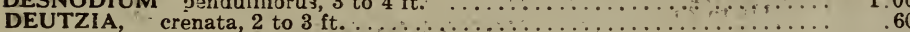
crenata Alba, 2 to $3 \mathrm{ft}$.

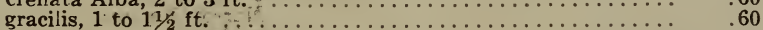

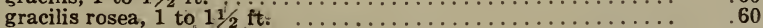

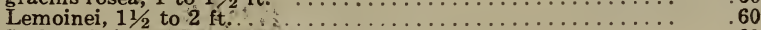

Scabra, Pride of Rochester, 2 to $3 \mathrm{ft}$.

ELDER, Golden, 2 to $3 \mathrm{ft}$.

FORSYTHIA, Morrowi, 2 to $3 \mathrm{ft}$. 3 to $4 \mathrm{ft}$. Suspensa, 2 to $3 \mathrm{ft}$ :

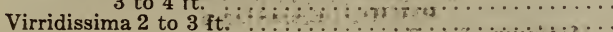
3 to $4 \mathrm{ft}$.

FRINGE, Purple, 2 to $3 \mathrm{ft}$.
HONEYSUCKLE, Fragrant, 2 to $3 \mathrm{ft}$.

Red Tartarian, 2 to 3 ft.

White Tartarian, 2 to 3 ft.

HYDRANGEA, arborescens, $11 / 2$ to $2 \mathrm{ft}$. to $4 \mathrm{ft}$

\section{paniculata 2 to $3 \mathrm{ft}$} 3 to $4 \mathrm{ft}$

Tree-form. 3 to $4 \mathrm{ft}$.

KERRIA aponica, $11 / 2$ to $2 \mathrm{ft}$

LILAC,

Purp!e, 2 to $3 \mathrm{ft}$.

3 to $4 \mathrm{ft}$.

White 2 to $3 \mathrm{ft}$.

10.00
6.00

6.00

6.00

6.00

6.00

6.00

6.00

6.00

7.50

6.00

7.50

6.00

7.50

6.00

6.00

6.00

7.50

6.00

7.50

$\begin{array}{rr}1.00 & 10.00 \\ .75 & 7.50 \\ .75 & 7.50\end{array}$

$\begin{array}{rr}1.00 & 10.00 \\ .75 & 7.50 \\ .75 & 7.50\end{array}$

$\begin{array}{rr}1.00 & 10.00 \\ .75 & 7.50 \\ .75 & 7.50\end{array}$

$\begin{array}{ll}1.00 & 10.00 \\ 1.25 & 12.50\end{array}$

1.25
.60

.60
.60

$.75-7.50$

$60-6.00$

7. 50

HIGH BUSH CRANBERRY, 2 to $3 \mathrm{ft}$.

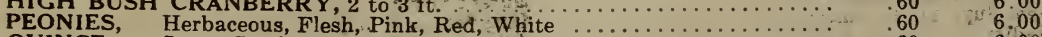

QUINCE, Japan Scarlet, 2 to $3 \mathrm{ft}$.

SNOWBALL, Common, 2 to $3 \mathrm{ft}$.

\section{SYMPHORICapan, 2 to $3 \mathrm{ft}$.}

6.00

6. 00

7.50

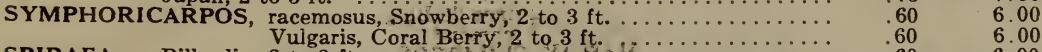

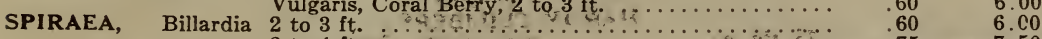

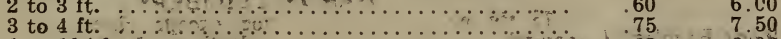

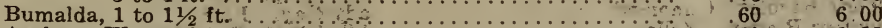

Anthony Waterer, 1 to $11 / 2 \mathrm{ft}$.

Callosa, Pink, 2 to $3 \mathrm{ft}$ :

Callosa alba (White), 1 to $11 / 2 \mathrm{ft}$

Opulifolia aurea, 3 to $4 \mathrm{ft}$.

Opulifolia aurea, Golden, 2 to $3 \mathrm{ft}$

6.00

6.00

6.00

Syringa, Common, 4 to $5 \mathrm{ft}$. 


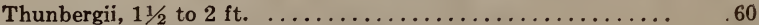

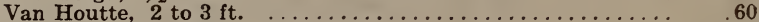

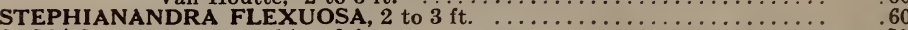

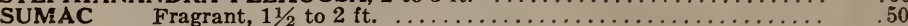

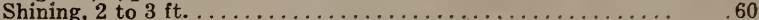

Smooth, 3 to $4 \mathrm{ft}$.

Staghorn, 3 to $4 \mathrm{ft}$.

SWEET PEPPER BUSH, $11 \frac{1}{2}$ to $2 \mathrm{ft}$. .

Common 3 to $4 \mathrm{ft}$.

4 to $5 \mathrm{ft}$.

TAMARIX, Africana 3 to $4 \mathrm{ft}$.

Indica, 3 to $4 \mathrm{ft}$.

Odessana 3 to $4 \mathrm{ft}$.

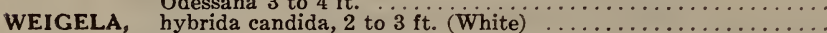

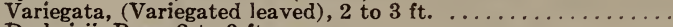

Desboisii, Rose, 2 to $3 \mathrm{ft}$.

Rose-colored, Rose, 2 to $3 \mathrm{ft}$. . . . .

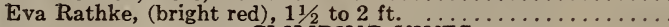

\section{CLIMBING VINES}

AMPELOPSIS, quinquofolia, 2 yr. No. 1

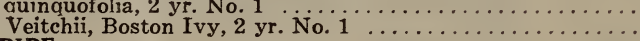

DUTCHMAN'S PIPE

HONEYSUCKLE Hall's Japa $n$

Japan Golden leaved $\ldots \ldots \ldots \ldots \ldots \ldots \ldots \ldots \ldots \ldots \ldots \ldots \ldots \ldots$

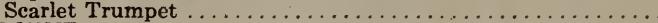

MATRIMONY VINE ...

WISTARIA, Chinese.

Purple

\section{CLEMATIS}

Strong 2 yr. plants

EDWARD ANDRE, Brilliant Red . . . . .

HENR YI, Best large white . . . . . . . .

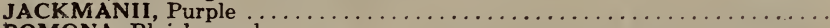

POMONA, Bluish purple

PANICULATA, Fragrant, White

\section{EVERGREEN SHRUBS}

$\$ 10.00$

10.00

10.00

in. 00

7:50

LEUCOTHOE CATESBAE 12 to 18 in

$\$ 25.00$

10.00

15.00 $11 / 2$ to $2 \mathrm{ft}$

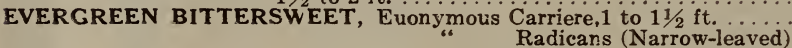

$$
\begin{aligned}
& 1 \text { to } 11 / 2 \mathrm{ft} . \ldots \ldots \ldots \ldots .75 \quad 7.50 \\
& 11 / 2 \text { to } 2 \mathrm{ft} . \ldots \ldots \ldots \ldots . \quad 1.00 \quad 10.00
\end{aligned}
$$

Ile Crenata (Japan Holly), 1 to $11 / 2 \mathrm{ft}$. ........... 2.00

RHODODENDRON, Maximum, 2 to $3 \mathrm{ft}$.

\section{.85 each $\$ 8.50$ per doz. except where noted}

American Beauty

Anne de Diesbach

Alfred Colomb

Baron De Bonstetton

Black Prince

Persian Yellow

Fisher Holmes

Frav Karl Druski

Gen. Jaequeminot

Chateau De Cles Vougeot

Dorothy Page Roberts

Gen. Superior A. Jansson

Hadley

Kaiserin Augusta Victoria

Killarney, $\$ 1.00$ each

Whíte Killarney

\section{HARDY CLIMBERS}

Hugh Dickson

Magna Charta

Margaret Dickson

Marchal P. Wilder

Mrs. John Laing

Paul Neyron

Princ Camilla de Rohan

Ulrick Brunner

\section{HYBRID TEAS}

La France

Laurent Carle

Marquise De Sinely

Melody

Mrs. Cynthia Forde

Pharisaer

Prince de Bulgaria

Richmond

75 cts. each, $\$ 7.59$ per doz. except where noted

Alberic Barbier Lemon-white

Aviateur Bleriot. Ye!low

Baltimore Belle. Pínk

Blue Rambler. Bluish tint

Bordeaux Pink

Crimson Rambler. Red

Dorothy Perkins. Pink

American Fillar, $\$ 1.00$ eaeh
Lady Gay. Pink

Philadelphia Rambler. Crimsôn

Piller of Gold. Yellow

Queen of the Praíríe. Red

Pink Rambler

Seven Sisters. Pink

Silver Moon. Single, White

Tausendschon (Thousand Beauties) Light Pink 
Dr. Van Fleet

Excelsa (Red Dorothy Perkins)

Flower of Fairfield

Cardenia, (Hardy Marechal Niel)

Hiawatha. Single, Red
Wichuraiana. Single, Scarlet Wm. C.Eagan. Flesh Color

\section{BABY RAMBLERS $\$ 1.00$ each \\ Pink Crimson "Baby Rambler \\ White \\ PERENNIALS}

25 cts. each, $\$ 2.50$ per dozen, $\$ 20$ per 100

\section{Common Name}

Achillea, The Pearl

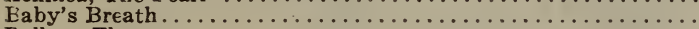

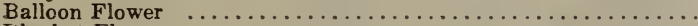

Blanket Flower . . . . . . . . . . . . . . . . . . . .

Blue-Bird Flower . . . . . . . . . . . . . . . . . . . .

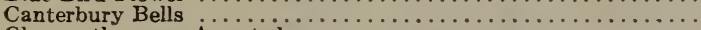

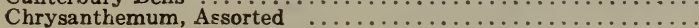

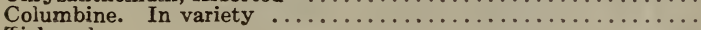

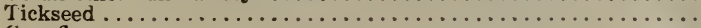

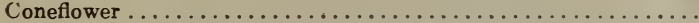

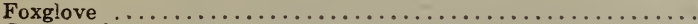

Golden Glow

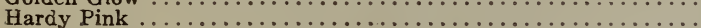

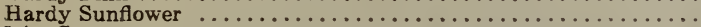

Iris, German . . . . . . . . . . . . . . . . . . . . . . .

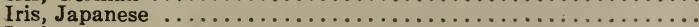

Larkspur

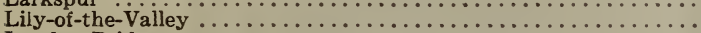

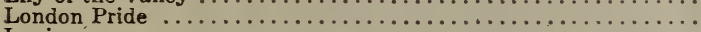

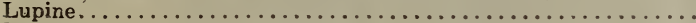

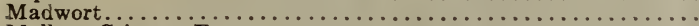

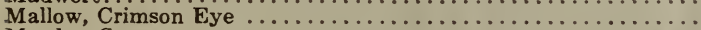

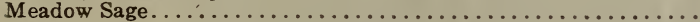

Uswego Tea

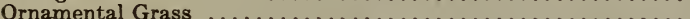

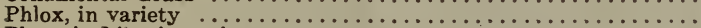

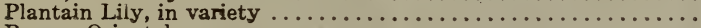

Poppy, Oriental . . . . . . . . . . . . . . . . . . . . . . . .

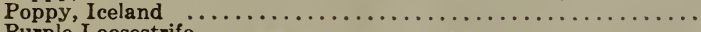

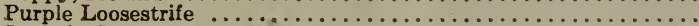

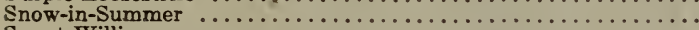

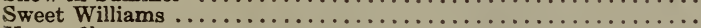

Yucca filamentosa

Mallow Marvels, Red, Pink, White, .50 each. $\$ 5.00$ per dozen
Botanical Name

Gypsophila

Platycodon

Gaillardia grandiflora

Veronica Longifolia subsessili Campanula Media

Aquilegia

Coreopsis lanceolata

Rudbeckia maxima

Digitalis

Rudbeckia laciniata

Dianthus plumarius

Helianthus Pitcheriana

Iris Germanica

Iris Kaempferi

Delphinium

Convallaria majalis

Lychnis chalcedonica

Lupinus polyphyllus

Alyssum saxatile compactum.

Hibiscus

Salvia azurea grandiflora

Monaida didyma

Eulalia japonica

\section{Funkia}

Papaver orientale

Papaver nudicaulo

Lythrum Roseum Superbun

Cerastium tomentosum

Dianthus barbatus 


\section{SPECIAL GRADES OF PEACH AND APPLE TREES}

When we have completed the grading of our stock, we always find a limited quantity of trees, which for one reason or another, have not made the growth that is shown by the block as a whole. Many times there are portions of rows where seed eame up thicker so that the trees may have stood too close, which, as in every living production of nature, causes some of them to grow smaller than others but when these trees are planted singly by themselves and given good care, they inevidently thrive and grow well. The root system is jusually much heavier in proportion in these small trees than with larger ones, which accounts for the fine growth usually made aftertransplanting. We can supply the following varieties in special size;
Belle of $\mathrm{Ga}$.
Champion
Carman
Elberta
Fox Seedling
Greensboto as ats

1 to $2 \mathrm{ft}$.
J. H. Hale

Mt. Rose

Mayflower

Nectar

Old Mixon

Ray

Each

$\$ .50$
Doz.
Stump

Waddell

Eva

Anita

Tena

Toughina

$\begin{array}{ll}100 & 1000 \\ \$ 35.00 \quad \$ 300.0\end{array}$
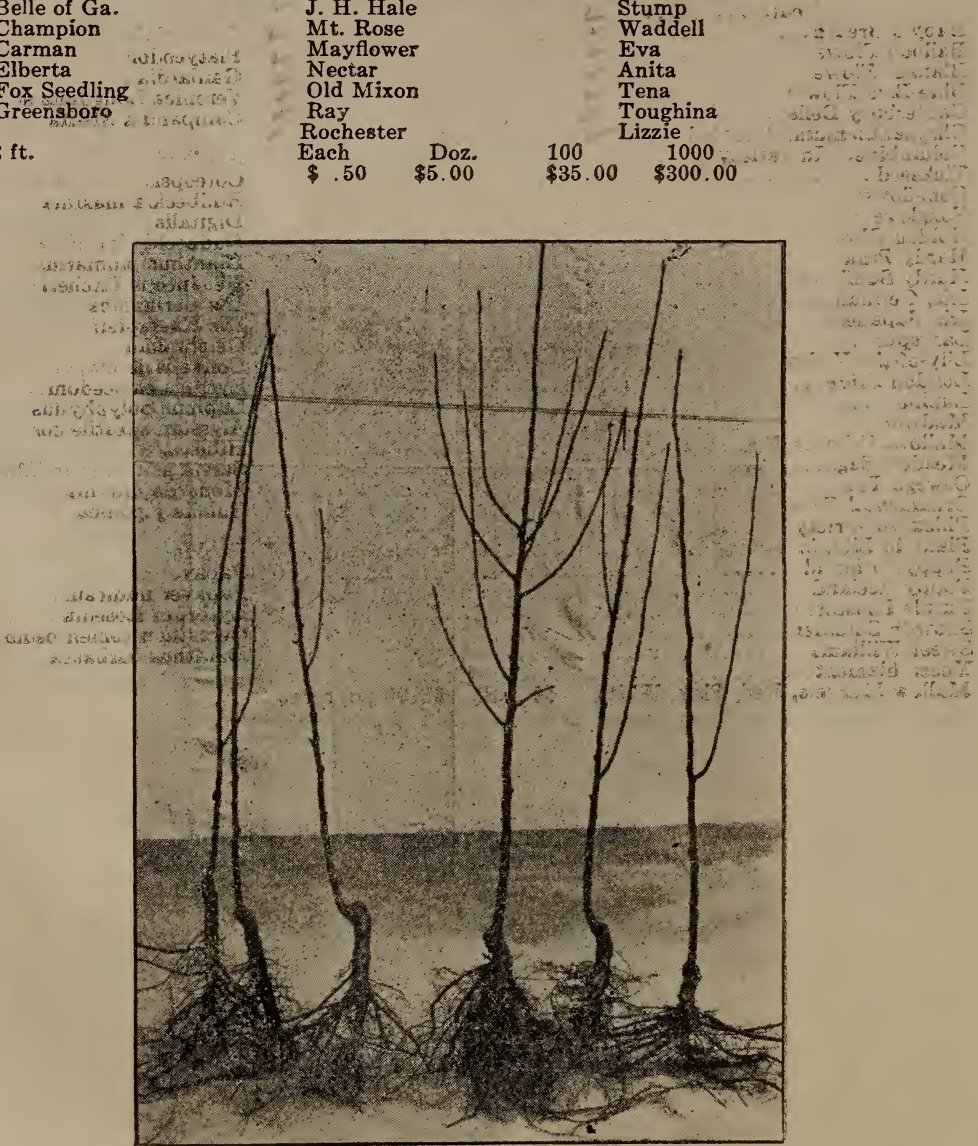

This picture shows a few of our special grade, two year apple trees, $3 / 8-1 / 2$ " caliper, $3-4 \mathrm{ft}$ in height. They are a bargain. If not ready to plant this year, line them out in your garder and with good care, they will double in size before another fall and represent a value of two or three times their first cost.

We have offered a special grade of $3 / 8^{-1} / 2^{\prime \prime}$ trees for the past two seasons. The explanation regarding peaches will also apply to this grade of apples. We give below, extract taken from a circular issued last year.

"We can furnish a limited quantity of trees as above, first class in every respect except in size, absolutely free from disease and with roots better than many large trees. We offered a few of these one year ago and advised at that time as follows. "If you don't feel ready to plant a large number this spring, line them out in a trench in your garden. They will double in size the next summer and represent a real bargain when you wish to plant the following season." Time has proven the truth of this statement. We again offer this same suggestion. Trees will be high 
for several years owing to a decided shortage of stock to propagate upon. A good deep furrough plowed out both ways will be sufficient to line these out, eight or ten inches apart, and then till them the same as a good corn crop.

Planted in permanent places, they will give just as good results and in five years will be as large as a tree double its size in the beginning."

We again offer the same advice which we did last year and the year previous. A word to the wise is sufficient.

$\begin{array}{lllll}3 / 8-1 / 2^{\prime \prime}, \text { cal. } 3-4 \mathrm{ft} . & \text { Each } & \text { Doz. } & 100 & 1000 \\ & \$ .50 & \$ 5.00 & \$ 35.00 & \$ 325.00\end{array}$

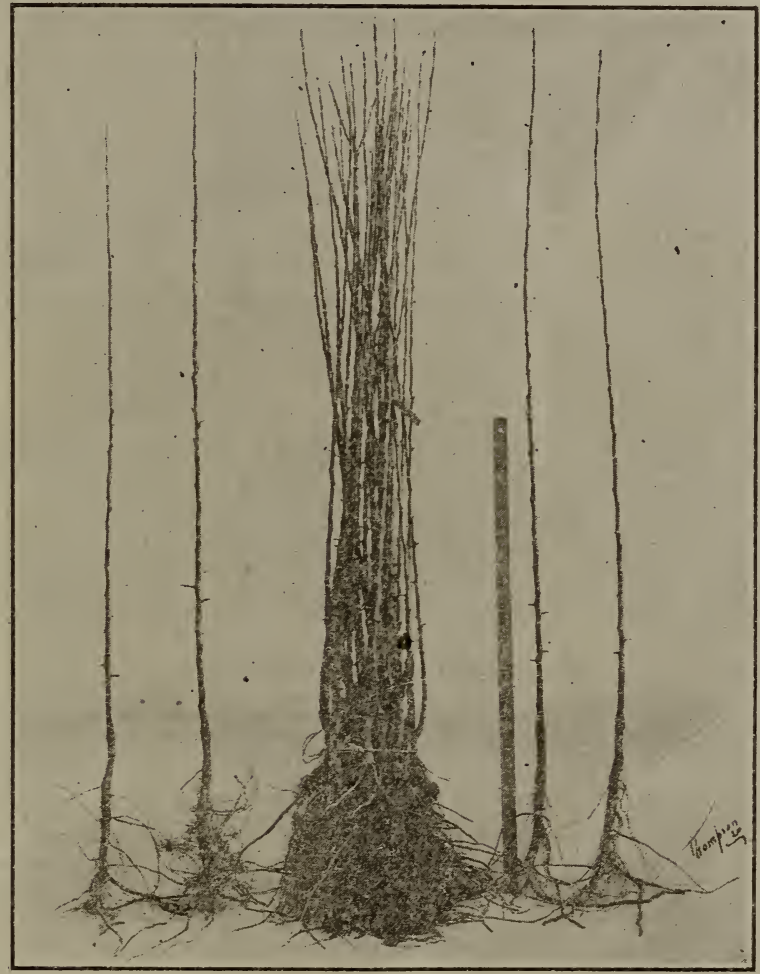

A few one year old Wagner apple trees. Note the heavy fibrous root systems. It is this large root which accounts for the success in planting apple trees one year of age.

Notice the yard stick showing comparative height of the trees. We grade them from three to ive feet although some of them may run more.

\section{ONE YEAR APPLE TREES}

Our block of one year apple trees, while the smallest we have ever grown, we believe has never been excelled in thriftiness and quality. It is a beautiful sight to see these straight, thrifty trees, many standing higher than one's shoulders. Many planters prefer a one year tree since they can then start the top just as wished.

We offer as follows in one year apple trees:

McIntosh, Stzyman Winesap, Wealthy, Delicious, Duchess, Williams.

$3-5 \mathrm{ft}$

Each Doz.

$2-3 \mathrm{ft}$

$\$ .95$

$\$ 9.50$

7.50

100

$\$ 75.00$

1000

Other varieties 3 to $5 \mathrm{ft}$.

$\$ 75$

$2-3 \mathrm{ft}$.

.60

Terms same as in regular price list.

$7.50 \quad 55.00$

$\$ 700.00$

500.00

$6.00 \quad 45.00 \quad 400.00$

$5 \%$ discount for cesh with order on all prices in this circular. 


\section{STRAWBERRIES \\ (For Spring Planting Only)}

Strawberries offer one of the greatest opportunities for profit today. There is a very decidef shrrtage of berry fruits in the market, which is noticeable in the extremely high prices which the fruit brought this past season, having very commonly retailed at .40 per quart-a very common yield for well cared for strawberry fields is 100 bushels. This fruit is especially desirable planted among small fruit trees, where returns are obtained the 2 nd year. Thus the fruit trees will be reared to bearing age without cost and represent so much extra profit aside from the actual profit returned by the berries.

Strawberries make an ideal crop to use in rotation, follcwing as it does Asparagus, in fact they often commence to ripen just before the end of the Asparagus season, continuing into July and followed directly by Raspberries. There is no need for the farm to be without returns anytime during the season.

In sections adjacent to heavy traffic, near cities and especially near summer resorts, there is no end to the possibilities of developing a high class retail trade from autoists, who will come to your very door and gladly pay the top price for "fresh fruit."

Any good farm land will grow strawberries, but they do their best on a rich well drained sandy loam soil, such as would give the best result with corn; in fact corn makes a fine crop to precede strawberries, plowing in, if possible, a good dressing of stable manure.

Do not stint a strawberry crop or begrudge it a good dressing of chemical fertilizer in addition to the stable manure. No crop will any better return good dollars for good care and attention.

Thru an oversight in making up our catalogue, a few varieties of strawberries which we are growirg were left out and we give herewith a description of those which are worthy the attention of any berry grower.

Bubach-(Imp)-Early to mid-season, - fruit very large and of a bright beautiful redberries thick, meaty, fine grained, often weighing an ounce and a quarter each. Fine for local market but will not stand shipping.

Early Jersey Giant-(Per.) - The best early strawberry we know of-berries large deep rad and of uniform heart shape. Don't miss this one.

Excelsior-(Per)-The earliest variety we carry. Fruit of medium size but always bring good prices being the first in the market.

Missionary - (Per) - A very early berry much grown in the south, although it does well in the rorthern and middle Atlantic States. Early berries usually bring higher prices than mid-season although in these times there is no danger of over-production and the heavier producing mid-season berries should make up the bulk of the planting with a few early varieties as a starter.

Prolific-(Per) - This enormously productive variety was produced by the New York Experiment Station and named Prolific on account of its heavy yields. It is one of the newer varieites and not so well known as many of the older sorts, but it surely will make itself heard from.

Senator Dunlap-(Per) - An old standard variety, sturdy and heavy producers.

Wm. Belt-Large and handsome fruit, bright red dotted with golden yellow seeds, unsur passed for table use.

\section{EVERBEARING STRAWBERRIES}

The finest addition to our list of fruits in recent years. In addition to producing a crop in early summer, they again begin to bear in August and continue until freezing weather-even in the north-it is not uncommon to find berries which have been somewhat protected fuliy mature in November. Their principal use is for home planting but the fruit always brings extremely high prices being especially in demand at banquets or high class hotels.

Progressive-There seem to be many so-called everbearing berries, but the number that actually answers the desaription is small. Of these we believe Progressive tops the list. It is pre-eminently a home-garden berry, although the fruit may be shipped short distances if properly packed. The method of raising these berries is the same as for the other sorts, excepting that for the first season all blossoms that come before the first or middle of July should be cut off. The berries are of medium size but the plants bear so freely that one forgets the size and is amazed at the quantity; and the supply does not fail until after the severe frosts come. The berries are delicious durirg the whole season.

Superb-This variety is well named, and it is often a question whether Superb is not the equal of Progressive. So far as grow th is concerned the two are almost identical, but Superb does not bear such great clusters of fruit. Superb seems to be a better variety for the North than the South. It is a good variety for home-gardens or for growing on a large scale for market. The fruit is firm, ships well, and appeals to the buyer who caters to a high-class trade as well as to the consumer who likes to have delicious berries late in the year.

\section{NOTE}

Since our catalogue was sent to print, we have sold out our entire stock in the following varieties of Grapes; Brighton, Niagara, Salem and Worden. 